BULLETIN Bulletin hispanique

HISPANIQUE Université Michel de Montaigne Bordeaux

115-1 | 2013

Poésie et société en Espagne : 1650-1750

\title{
Los Entretenimientos del numen (1738) de Torres Villarroel
}

antología poética y vida literaria

Ignacio García Aguilar

\section{(2) OpenEdition}

\section{Journals}

Edición electrónica

URL: http://journals.openedition.org/bulletinhispanique/2379

DOI: 10.4000/bulletinhispanique.2379

ISSN: 1775-3821

\section{Editor}

Presses universitaires de Bordeaux

\section{Edición impresa}

Fecha de publicación: 1 junio 2013

Paginación: 97-123

ISBN: 978-2-86781-898-1

ISSN: 0007-4640

Referencia electrónica

Ignacio García Aguilar, «Los Entretenimientos del numen (1738) de Torres Villarroel », Bulletin

hispanique [En línea], 115-1 | 2013, Publicado el 01 junio 2016, consultado el 01 mayo 2019. URL http://journals.openedition.org/bulletinhispanique/2379; DOI : 10.4000/bulletinhispanique.2379 


\title{
Los Entretenimientos del numen (1738) de Torres Villarroel: antología poética y vida literaria ${ }^{1}$
}

\author{
IgnaCio García Aguilar \\ Universidad de Córdoba
}

Cet article propose l'analyse des "Juguetes de Talía, entretenimientos del numen" (1738) de Diego de Torres Villarroel comme une tentative de créer, au moyen du livre de poèmes, l'autobiographie poétique ou la vie littéraire d'un professionnel moderne de la poésie dans son contexte social.

Mots-clés : Diego de Torres Villarroel, Juguetes de Talía, entretenimientos del Numen, poésie imprimée.

El presente artículo se centra en el estudio de los "Juguetes de Talía, entretenimientos del numen» (1738) de Diego de Torres Villarroel como un intento de crear, mediante el libro de poemas, la autobiografía poética o vida literaria de un moderno profesional de la poesía en su contexto social.

Palabras claves: Diego de Torres Villarroel, Juguetes de Talia, entretenimientos del numen, poesía impresa.

The present paper focuses on the study of Diego de Tores Villarroel's "Juguetes de Talía, entretenimientos del numen" (1738), as an attempt of creating, by means of the book of poems, the poetical autobiography, or literary life of a modern professional of the poetry in his social context.

Keywords: Diego de Torres Villarroel, Juguetes de Talía, entretenimientos del Numen, printed poetry.

1. Este trabajo se ha realizado en el marco del proyecto Arias Montano: Teología y Humanismo (FFI2009-07731).

Bulletin Hispanique, Tome 115, n 1 - juin 2013 - p. 97-123. 


\section{ENTRETENIMIENTOS PoÉticos en el Bajo Barroco}

En 1738 se publican en Salamanca los Juguetes de Talia, entretenimientos del numen, recopilación de varias poesías de Diego de Torres Villarroel, como reza el subtítulo. Con la misma etiqueta, pero ampliando significativamente la recopilación de textos, vuelve Villarroel a publicar su poesía en 1744 y en los volúmenes VII y VIII de sus obras completas, estampados en 1752. Lo primero que llama la atención del volumen de 1738, por lo inusual, es justamente el rótulo intitulador con que se designa al libro. La apelación a una o varias musas del Parnaso (Talía, en este caso) no resultaría extraña para la organización poemática de una obra cerrada, o al menos no lo sería en la centuria anterior, cuando Quevedo instaura editorialmente en la tradición poética castellana un paradigma cuyos valores dispositivos tuvieron una tímida fortuna posterior ${ }^{2}$. Pero Talía no auspicia en Villarroel una obra completa ni el itinerario de una escritura acabada, sino una obra en proceso que acaso pudiera compartir con parnasos precedentes las «descripciones graciosas, sucesos de donaire y censuras satíricas» con que describió Quevedo a su musa homónima, estandarte de la comedia y lo bucólico.

Pero más llamativo que esto resulta, por su infrecuencia, el maridaje de entretenimiento y poesía que sugiere la etiqueta usada para designar al volumen. Y de hecho, tras indagar en diversos catálogos y listados ${ }^{3}$, no hemos podido localizar ninguna otra recopilación o antología en la que la noción de «entretenimiento» se utilice como marbete designativo para la poesía, al margen del Entretenimiento de las musas (1654) de Torre y Sevil, del que nos hemos ocupado en otro lugar ${ }^{4}$, o del heterogéneo Bureo de las musas y honesto entretenimiento (1659) de Salvador Jacinto Polo de Medina, que contiene poesía, aunque no es un libro de poemas 5 .

El Entretenimiento de las musas de Torre Sevil se construye sobre la imagen conceptual, pero también material, de una baraja de cartas, de manera que

2. Sobre esto vid. Manuel Ángel Candelas Colodrón, «El modelo de Quevedo», en I. García Aguilar (ed.), Tras el canon. La poesía del barroco tardio, Vigo, Editorial Academia del Hispanismo, 2009, p. 25-39.

3. $\mathrm{Ni}$ en las búsquedas realizadas en la BNE ni en el portal del Catálogo Colectivo del Patrimonio Bibliográfico Español hemos podido localizar otras obras distintas a las de Torre y Sevil o Polo de Medina. Tampoco en recopilaciones aproximativas más específicas como nuestro «Listado de poesía impresa entre 1650 y 1700», en I. García Aguilar, op. cit., p. 231-243; ni en el trabajo posterior de Alain Bègue, «Relación de la poesía española publicada entre 1648 y 1750», en A. Egido y J. E. Laplana, La luz de la razón. Literatura y cultura del siglo XVIII. A la memoria de Ernest Lluch, Zaragoza, Institución Fernando el Católico, 2010, p. 399-477.

4. Ignacio García Aguilar, "Trocar el libro por la baraja”: eutrapelia y poemario impreso», Bulletin Hispanique, no 113.1, 2011, p. 103-128; y «El Entretenimiento de las musas (1654) de Torre y Sevil: nuevas vías dispositivas para la poesía impresa del Bajo Barroco", Calíope. Journal of the Society for Renaissance and Baroque Hispanic Poetry, no 18.1, 2012, p. 127-166.

5. El volumen de Polo de Medina es una recopilación de prosa de ficción en la que se intercalan, sin embargo, algunas composiciones poéticas. Lo imprimió Juan de Ybar, en Zaragoza, en 1659, y fue costeado por José Alfay. 
los distintos palos o manjares (como se denominan en el libro) sirven para la organización de las composiciones en torno a las nociones de poesía religiosa (oros), heroica (espadas), lírica (copas) y burlesca (bastos). El volumen se convierte así en un molde original y suficientemente flexible en el que acoger los textos (seleccionados) de una vida literaria en proceso, de la que se da cuenta en los epígrafes que encabezan los poemas.

En sus páginas se alojan piezas surgidas en los certámenes, justas o cualquier otra ocasión suscitada por los patrones de sociabilidad literaria en los que se desenvolvía el autor; esto es, la Zaragoza de mediados del XVII, tan determinada en lo político por los cambios dinásticos y en lo cultural por el vigor económico y letrado de su estructura urbana ${ }^{6}$. En este contexto ciudadano nace un producto que es fiel reflejo de cuán múltiples y variadas resultan las imbricaciones entre la poesía como formalización puramente textual y la sociedad en que esta se concreta; pues variados y heterogéneos resultan los modos en los que la poesía interfiere en la sociedad, determinándola, al tiempo que es influida por ella en su propia textualización.

Torres Villarroel era muchas cosas, y entre ellas un tahúr avezado, como queda de manifiesto en el prólogo de El gallo español (1725), en el que afirma: «soy escritor tahúr, que conozco la mano»'. En el poema titulado Cuenta un sopón, sirviente de estudiante, su vida a otro amigo, impreso en los Entretenimientos (1738), se realiza un inventario de los escasos bienes de que dispone quien escribe, poseedor únicamente de «una espada, un broquel y tal cual caja; / de comedias un libro, una baraja, / dos sillas cojas, un arquetón malo / y una mesa que tiene pie de palo» ${ }^{8}$.

Se puede presumir que quien así se expresaba habría sabido apreciar una propuesta como la ensayada por el poeta-tahúr que era Francisco de la Torre y Sevil. Conocía el Piscator, además, las celebraciones literarias de la ciudad aragonesa, pues participó en diversos certámenes vinculados con la Virgen del Pilar y con la Universidad de Zaragoza. Sin embargo, no es posible asegurar que Diego de Torres Villarroel conociera el poemario de Torre y Sevil, y mucho menos que los vínculos que establece el aragonés entre "poesía» y «entretenimiento" influyeran, varias décadas más tarde, en el catedrático salmantino a la hora de formalizar su libro. Pero es innegable que ambos volúmenes, semejantes en lo que respecta a la concepción del ocio o entretenimiento poético en el contexto del mercado del libro, son de una originalidad única en el panorama editorial y literario del Bajo Barroco, así como en sus respectivos contextos particulares.

Tanto uno como otro autor recopilan en vida una selección de sus composiciones y continuaron, en los ańos sucesivos, publicando lo ya impreso:

6. Para las características de ese entorno letrado vid. Pedro Ruiz Pérez, «La edición zaragozana a mediados del siglo XVII y la sistematización del libro de poesía», Bulletin Hispanique, n 113.1, 2011, p. 69-101.

7. Diego de Torres Villarroel, «A quien quisiere leer», en El gallo español, Madrid, Gabriel del Barrio, 1725 .

8. Diego de Torres Villarroel, Juguetes de Talía, entretenimientos del numen, Salamanca, Imprenta de la Santa Cruz, por Antonio Villarroel, 1738, p. 218-219. 
Torre y Sevil en su traducción de John Owen, de $1674^{9}$, y Villarroel en las obras completas que estampó en 1752. También ambos, para la concreción de sus entretenimientos, tuvieron en cuenta lo difundido y publicado con anterioridad en justas, certámenes, preliminares de libros o pliegos variados, dotando a los textos, sin embargo, de sentidos distintos a los originarios, por medio del nuevo contexto material y conceptual que ofrecía el libro unitario, en cuya secuenciación el macrotexto funciona estableciendo entre los poemas vínculos que no se encuentran ni en la ocasión esporádica ni en el impreso aislado.

Con todo, la hipótesis de una influencia del Entretenimiento de 1654 en el de 1738 no es algo que se pueda sostener mediante elementos objetivables. Y aunque es cierto que cada uno de estos libros supone una auténtica rara avis en su coyuntura editorial, las posibles concomitancias entre la rotulación y la conceptualización de ambos poemarios no ofrecerían, de seguro, conclusiones de interés con la solidez suficiente como para defender una interrelación necesaria y unívoca. Por tanto, no es el objeto del presente trabajo comparar uno y otro volumen; ni tan siquiera sugerir que debiera existir un vínculo necesario entre ambos entretenimientos.

Sin embargo, y dado que resulta innegable la exclusiva originalidad de uno y otro impreso, así como la apelación de ambos a un referente de mercado en el que la poesía se relaciona con el entretenimiento y el ocio, en las consideraciones sobre el poemario de Villarroel no se ha querido obviar el planteamiento de rupturista modernidad propuesto por Torre y Sevil ya en 1654, pues ambos libros resultan sintomáticos de los cambios que la poesía estaba sufriendo en los modelos de sociabilidad de su época. Además, en ambos volúmenes, los vínculos entre la poesía y el entretenimiento lúdico orientan buena parte de las composiciones hacia la senda de lo jocoserio ${ }^{10}$, lo que constituye un elemento de modernidad definitorio de propuestas poéticas innovadoras. Este tono o estilo es una característica distintitva de la producción torresiana, pues por medio de lo jocoserio Torres Villarroel "pone en entredicho la seriedad ontológica y epistemológica del sentido único, desenmascarando con ello la sacralizada identidad de la moralidad metafísica» ${ }^{11}$.

Desde luego, las circunstancias de uno y otro volumen eran muy distintas, pues los entretenimientos eran ya muy otros a la altura de 1738. Sin embargo, la opción por lo lúdico poético, que se concreta en ambos volúmenes, en mayor o menor medida, a través de lo jocoserio, y el compartido interés por dar cuenta de las circunstancias históricas de los textos en el itinerario del libro son factores que nos permiten formular hipótesis acerca de las posibles líneas de continuidad o ruptura que determinan los modelos de sociabilidad literaria de una diacronía poética extensa como es la del Bajo Barroco.

9. Francisco de la Torre y Sevil, Agudezas de Juan Oven traducidas en metro castellanos, ilustradas con adiciones y notas, Madrid, Francisco Sanz, Imprenta del Reino, 1674.

10. Sobre este concepto y su novedoso sentido distanciador vid. Jean-Pierre Étienvre, «Primores de lo jocoserio», Bulletin Hispanique, no 106.1, 2004, p. 235-252.

11. Emilio Chavarría Vargas, Transtextualidad y burla. Lo jocoserio en las sátiras menipeas de Diego de Torres Villarroel, Benalmádena, e.d.a. libros, 2011, p. 18. 


\section{Los ENTRETENIMIENTOS DE Villarroel: POeMARio en COYUNTURA}

El acercamiento a Los entretenimientos del numen (1738) de Villarroel nos ofrece la posibilidad de continuar indagando en una línea de análisis iniciada con el Entretenimiento de las musas (1654), lo que nos permitirá conectar el presente estudio con algunas de las hipótesis y propuestas interpretativas señaladas en trabajos anteriores sobre los poemarios impresos del Bajo Barroco. Será esta una vía idónea para reflexionar acerca de ciertos factores definitorios de la relación entre poesía y sociedad en la España del período 1650-1750, marbete que auspicia la monografía que nos ocupa. Cabría destacar, de entre esos factores, los siguientes: el sentido de los cambios que se operan en los conceptos asociados al ocio poético durante el Bajo Barroco; la relación con los modelos literarios previos; las situaciones que propician la escritura de poesía y los nuevos espacios en los que se integra y desenvuelve el poeta; la manera en la que se formalizan editorialmente los resultados de una escritura poética surgida en un contexto cambiante; o el modo en el que un yo diferente al de la centuria anterior se vale de los recursos textuales, pero también de la materialidad del libro y de las posibilidades paratextuales que este ofrece, para proyectarse en la sociedad no de manera individual, sino personalista.

Torres Villarroel es, con toda probabilidad, el mayor exponente de la profesionalización literaria del XVIII español. Autor de casi ciento cincuenta impresos en $v i_{a}{ }^{12}$, su biografía y su obra están bien estudiadas en lo que corresponde a los pronósticos y a la prosa de ficción. Sin embargo, la poesía del Piscator se encuentra en una parcela mucho más desatendida de su producción, y ello a pesar de haber estampado en vida una notable cantidad de poemas, lo que resulta indicativo del éxito de su propuesta.

La opción por analizar, de entre toda la poesía torresiana, el volumen de 1738 obedece, desde una perspectiva general, a lo ya apuntado acerca del valor de este libro como posible vía para un mejor entendimiento de ciertas características de la poesía y la sociedad bajobarrocas. Pero además de esto, desde un punto de vista particular, y en relación con la trayectoria literaria del salmantino, es importante destacar que en el ańo 1738 ocurren sucesos importantes que resultan indicativos de un profundo cambio en la perspectiva profesional de Torres Villarroel, así como también en la manera en la que decide gestionar la comercialización de su obra.

De acuerdo con el análisis por períodos que Guy Mercadier ${ }^{13}$ estableció para trazar la biografía del Piscator, los Entretenimientos se imprimen en el comienzo del cuarto período de su vida, el que abarca los ańos comprendidos entre 1738 y 1751. Se conoce poco de este lapso temporal, probablemente porque el propio

12. Para un listado exhaustivo de las obras impresas de Villarroel vid. el apéndice bibliográfico de Guy Mercadier en Diego de Torres Villarroel. Máscaras y espejos, ed. Manuel María Pérez López, Salamanca, Edifsa, 2009.

13. Vid. Diego de Torres Villarroel, Vida, ed. Guy Mercadier, Madrid, Castalia, 1972, en donde el crítico establece los cinco períodos que se consideran representativos de la biografía torresiana: $1694-1720,1721-1726,1727-1737,1738-1751$ y $1752-1770$. 
Villarroel no dice nada en su Vida (1743) sobre los cinco años que median entre 1738 y 1743 . Pese a ello, es posible rastrear noticias de interés, aunque de manera menos explícita, en otros lugares de su obra.

En el mismo año en que se imprimen los Entretenimientos del numen, Antonio Villarroel, primo del Piscator, saca a la luz la edición de la Anatomía de todo lo visible e invisible (1738), que surge como resultado de refundir y ampliar el Viaje Fantástico (1724). En los preliminares de la Anatomía estampa el editor un extenso prólogo con abundante información sobre el contexto socioliterario en que se generaba y consumía la literatura del momento, así como también datos reveladores acerca de los avatares sufridos por la obra torresiana. Se queja entonces de las apropiaciones a que se han visto sometidos los escritos de su primo por parte de impresores de toda Espańa y denuncia, de igual manera, las falsas atribuciones de títulos que no se debían al numen torresiano. Además, expone unas consideraciones de gran interés sobre la función institucionalizadora del vulgo en el sistema literario de su época:

El escolar, el soldado y el artífice nunca pueden ser famosos sin el vulgo, y el que lo tiene de su parte no le falta aprobación alguna. Últimamente, el vulgo es la alegría, la confirmación, el grado de pompa y el dichoso despacho de los dichos, hechos, obras $\mathrm{y}$ acciones de los doctos y los valientes. Y hasta que la vulgaridad no los victorea y canoniza, no se conocen, y viven sin fama, sin crédito, sin nombre, sin gloria y $\sin$ $\operatorname{paga}^{14}$.

Siendo el vulgo el que canoniza, otorgando fama y dinero, sería importante que tuviera a su alcance un inventario autorizado de la producción del escritor, para mejor discernir y valorar la obra de este. Y tal vez fuera esa certeza la que indujo a Diego de Torres a añadir en su prólogo el repertorio de las obras escritas por su primo. La autenticidad del listado resulta indiscutible, pues fue confeccionado por el propio Piscator, con la intención de mostrar un retrato de su vida a través del conjunto secuenciado de su obra (literaria), como confiesa Diego de Torres al final de su prólogo:

Pongo aquí solamente el Memorial de ejercicios y trabajos hecho por el mismo don Diego, en el que contemplará el lector algún rasgo de su vida, mientras doy en más dilatado volumen la que ha días que escribió desde Portugal ${ }^{15}$.

Lo que se expone en estas breves líneas finales es importante por tres razones. En primer lugar, porque en ellas se valida la autoría indiscutible de la nómina de obras torresianas. En segundo lugar, porque se establece un correlato indisoluble entre vida y obra, o para ser más precisos, entre el Torres Villarroel profesional de las letras y la obra que justifica su estatus, resultado de largo tiempo de exitosa dedicación. Por último, la alusión final a la Vida que comenzó a redactar el Piscator durante su forzado retiro en Portugal indica

14. Prólogo de Antonio Villarroel y Torres, mercader de libros en Salamanca, en Diego de Torres Villarroel, Anatomía de todo lo visible e invisible, Salamanca, Antonio Villarroel, 1738.

15. Ibid. 
que Torres Villarroel se encontraba escribiendo (y difundiendo, al menos entre los cercanos) su más conocida autobiografía ficcional en prosa. Y todo ello durante los mismos días en que tenía en mente el proyecto de edición de sus Entretenimientos y de la Anatomía.

Los extensos preliminares de la Anatomía dejan lugar también para un prólogo del autor, en el que Torres Villarroel se retrotrae hasta sus años de juventud, cuando se inició en la escritura. En aquella época, según confiesa, se animó a continuar escribiendo por el reconocimiento que obtenía con sus obras. No obstante, y tras ańos de éxitos trufados de sinsabores, considera desde el presente de 1738 que es tiempo de detener su pluma para iniciar un nuevo (y lucrativo) proyecto, consistente en la recopilación y publicación de sus obras completas:

Me he determinado a recoger las necedades que andaban en jigote por este mundo $\mathrm{y}$ reducirlas a las albóndigas de siete $\mathrm{u}$ ocho tomos, para ver si me las vuelven a engullir los paladares tragallones ${ }^{16}$.

La imagen gastronómica de la carne picada (o jigote) que se convierte en volúmenes independientes (o albóndigas) resulta muy ilustrativa de hasta qué punto se mancha las manos el autor para cocinar de nuevo su obra y ofrecer a los lectores unos manjares idóneos con los que satisfacer al más amplio y variado gusto. Acerca de la heterogeneidad de su producción insiste más adelante, aportando interesantes nociones que conectan con el concepto del entretenimiento y los vínculos de este con la eutrapelia:

\footnotetext{
No quiero que mis lectores estén siempre melancólicos y engolillados sobre mis libros, que ellos y yo somos muy humildes y no gastamos cumplimientos con nadie: diviértete, desenfádate, oréate y ponte a tu gusto, que para estudiar, para leer ni para instruirse es necesario el ceño, la tristeza, la compostura ni la abstracción [...] has de ver entre los libros ancianos y mozos que se han hecho para entretener y enseñar muchos peores que este, pocos mejores y algunos tan buenos ${ }^{17}$.
}

La atención dispensada a la Anatomía, que pudiera parecer distractora o ajena al propósito principal de este trabajo, nos parece necesaria para poder contextualizar de modo óptimo la antología poética torresiana, ya que los vínculos entre la Anatomía y los Entretenimientos rebasan la mera coincidencia cronológica. Ello es así porque ambos volúmenes no solo se estaban preparando al mismo tiempo, sino que formaban parte de un proyecto editorial conjunto cuya salida al mercado se orquestó de manera simultánea, como lo prueba la existencia de un privilegio único para ambas obras, otorgado el veinticuatro de junio de 1738, que se imprimió idéntico en los preliminares de uno y otro libro.

16. Prólogo general de Torres, que no impide a los particulares de las demás Obras. Es largo, porque hay mucho que decir, en op. cit.

17. Ibid. 
Así las cosas, y de acuerdo con los datos expuestos, parece claro que 1738 es un año importante para Torres Villarroel, pues comienza entonces la recopilación y selección de sus escritos, con el objeto de convertirlos en volúmenes dosificables y digeribles para el gran público. Simultáneamente, había iniciado la redacción de su autobiografía ficcional en prosa, estampada algunos años más tarde. Por tanto, los Entretenimientos del numen se conciben, o al menos se concretan, en una temporada de importantes cambios en la trayectoria del autor, coincidente en el tiempo con el momento en que Villarroel decide dar cuenta de su ascenso social y justificarse como profesional de la escritura, lo que hace por medio de su Vida. Pero en este empeño tan personal (y personalista) no pasó por alto las posibilidades que ofrecía otro género editorial: el libro de poemas. Así pues, en sus Entretenimientos se sirve el Piscator de la materialidad del impreso para trazar lo que podría considerarse un retrato objetivable de su vida como poeta de mercado. Por todo ello, es posible considerar a Los entretenimientos del numen como una inflexión y una encrucijada en el itinerario profesional de Torres Villarroel.

Inflexión porque es el primer testimonio de una voluntad decidida por recopilar su propia poesía, ofrecerla al mercado y construir en el proceso una imagen (interesada, como no podía ser de otro modo) de su trayectoria letrada. Para ello recurre a la recopilación, aunque no íntegra, de muchas de las composiciones ya publicadas con anterioridad, modificándolas sin empacho cuando lo considera oportuno para adecuarlas al concepto de libro poético que desea componer: un volumen de poesía en cuya definición y trazado subyace mucha de la biografía literaria que desarrolla en su Vida en prosa, publicada en 1743, aunque iniciada algunos años antes, durante los días en que comenzó a recopilar las piezas poéticas con las que conformó su antología.

Pero además de inflexión, este volumen es una encrucijada, pues de las dos direcciones posibles, heterogénea y aglutinadora dispersión circunstancial o unidad editorial homogénea, se opta por la segunda. Conforme a esta opción, se sistematiza la obra poética dispersa y se procede a seleccionar lo que mejor encaja con el proyecto de poemario torresiano, confiriéndole a la secuencia poemática una cierta lógica discursiva en el orden dispositivo del libro. El camino elegido en este libro se continuará, con el mismo título e idéntico planteamiento, en los volúmenes séptimo y octavo de sus obras completas. Entonces, y tras dos décadas de continuada escritura, los Entretenimientos del numen se ensanchan para dar cabida a los poemas escritos en los años intermedios. Ello obliga a una reorganización del material poético, pero las modificaciones de índole formal no alteran la implícita noción de una vida poética en progreso que sirve como testimonio empírico del «itinerario burgués»" ${ }^{18}$ recorrido por el Piscator. Tal vida se muestra apegada, y mucho, a las circunstancias que originaron los textos, como testimonian con objetividad y precisión matemática los paratextos

18. Vid. Maria Grazia Profeti, "I Juguetes de Thalia, di Torres Villarroel: un itinerario "borghese"", en AA. VV., I Secoli d'Oro e i lumi. Processi di risematizzacione, Florencia, Alinea Editrice, 1998, p. 9-22. 
de los que estos se acompañan, los cuales igualan o superan en sus epígrafes la extensión (y precisión) de algunas de las piezas propiamente poéticas. La restitución del aqui y del ahora de cada poema reconstruye para el lector la circunstancia de la escritura, su historicidad pretérita, actualizándola en el presente inalterable del poemario, que se convierte entonces en testimonio de una obra en progreso y en notario fidedigno de un ascenso social que corre en paralelo a dicha obra.

Un poemario de ENTRETENIMIENTOS: Organización y SeNtido del NUMEN TORRESIANO

En 1732 el Diccionario de Autoridades definía el entretenimiento en su primera acepción del siguiente modo: «diversión, pasatiempo y lo demás que divierte y entretiene al hombre: como lección, estudio, juego, paseo, etc.». El concepto, por tanto, no había cambiado mucho desde los tiempos de Torre y Sevil. Pero también como a mediados del XVII, el vocablo tendía lazos, además, con referentes vinculados a lo crematístico («ayuda de costa, sueldo y merced pecuniaria»), a la dilatada morosidad ("dilación de alguna cosa o retardación de ella») y a la jocosidad lúdica («burla, trisca y juegos de manos o acciones y chanzas»).

La antología poética del Piscator no desdice de su título, pues en el interior de estos juguetes (de Talía) o entretenimientos (de Torres Villarroel) se encierran algo más de dos centenares de composiciones, que conforman un producto en el que se conjugan ocio, negocio y jocosidad.

El heterogéneo material poético se articula, a grandes rasgos, en tres extensos bloques de composiciones: sonetos, poemas varios con preponderancia de lo octosilábico y un poema épico en octavas sobre la conquista de Nápoles. Detallando algo más esta ordenación, de acuerdo con el criterio estróficotemático que rige la dispositio del volumen, es posible distinguir entre: sonetos morales (p. 1-32), sonetos amorosos (p. 32-73), tres silvas y una octava, dirigidas a Filis (p. 74-79), romances (p. 80-168), décimas (p. 168-172), liras (p. 173190), seguidillas (p. 190-199), redondillas (p. 200-219), quintillas (p. 220233), glosas (p. 234-243), coplas «de repente» (p. 244-248) y las octavas de que se compone la Conquista del reino de Nápoles (p. 249-301).

Como se ha indicado, el volumen se abre con una sección de sonetos varios, rotulados como morales (p. 1-32), que provienen en su mayor parte de una recopilación de los ya publicados doce años ante bajo el nombre de Ociospolíticos $(1726)^{19}$, aunque con alguna elisión y algún añadido posterior más cercano en el tiempo, como el soneto que escribió Torres Villarroel para los preliminares de

19. Diego de Torres Villarroel, Ocios políticos, Madrid, Isidro López del Hoyo, 1726. Para un acercamiento a esta obra vid. Irene Vallejo González, "Consideraciones sobre Ocios políticos, primer libro de poesías de Torres Villarroel», Edad de Oro, n³ 31, 2012, p. 11-37. 
las Glorias de España (1736) de Salazar ${ }^{20}$. En esta sección inicial trata Villarroel, desde una perspectiva mayoritariamente satírica, aspectos relacionados con la vida cortesana, la vida universitaria, los médicos, su vinculación con personajes concretos y reales como el marqués de Flores Dávila o su participación en fiestas ciudadanas y universitarias de Salamanca, entre otros asuntos. Esta poesía circunstanciada abarca, en suma, un amplísimo espectro de situaciones posibles, que van desde los textos dirigidos a una celebración regia ${ }^{21}$ hasta los escritos, por ejemplo, con motivo de la muerte de un caballo, dentro de un entorno de academia ${ }^{22}$, pasando por el chichisveo, práctica de cortejo muy extendida en la época y que critica Villarroel en el poema en que Habla con don Francisco de Quevedo en las sátiras a los cornudos:

Para cuatro cornudos vergonzantes, que usted alcanzó en su siglo ya perdido, hizo extremos y sátiras picantes.

Dé mil gracias a Dios no ser nacido, pues si hubiera alcanzado chichisvantes antes fuera cornudo que marido ${ }^{23}$.

La heterogeneidad de los temas y de su tratamiento no da lugar a un poemario deslavazado, pues existen diversos elementos que confieren coherencia y homogeneizan el macrotexto, tales como la omnipresencia del yo dual de Villarroel (el histórico y el ficcional) ${ }^{24}$, o ciertos motivos y preocupaciones que están presentes a lo largo de toda la variedad textual. Así, por ejemplo, la autojustificación reiterativa, la exaltación servil de la clase nobiliaria, la defensa de la práctica letrada o la preocupación por la propia práctica de la escritura, lo que conecta a los textos, las más de las veces, con referentes literarios del repertorio poético, perfilando en el proceso una posición clara ante el canon recibido. Así ocurre con el poema en que Dice el pago y el premio que da el mundo a los profesores de poesía $a^{25}$, refiriéndose para ello a Quevedo, Góngora y Calderón; o cuando se acude nuevamente al poeta madrileño: Con los mismos consonantes que don Francisco de Quevedo, desengaña a los soberbios de que su vanidad no puede hacerlos de mejor fortuna que a los mendigos ${ }^{26}$.

20. Op. cit., p. 31-32.

21. Op. cit., 7 y 20.

22. Op. cit., p. 8-9.

23. Op. cit., p. 12.

24. Renata González Verdasco ha estudiado cómo se plasman asuntos vivenciales del Villarroel histórico (tales como el destierro, la astrología, el viaje a Santiago y su larga enfermedad) a través del yo textual de varios de sus poemas, lo que le permite plantear que «Torres en su poesía tratará siempre del personaje Torres» («El yo en la poesía de Diego de Torres Villarroel», en Estudios dieciochistas en homenaje al profesor José Miguel Caso González, vol. I, Oviedo, Instituto Feijoo de Estudios del Siglo XVIII, 1995, p. 413-420).

25. Op. cit., p. 7-8.

26. Op. cit., p. 25-26. A Quevedo volvería a acudir Villarroel en muchas ocasiones. Además de las ya señaladas, cabría mencionar el soneto Con los mismos consonantes que don Francisco de Quevedo, desengaña a los soberbios de que su vanidad no puede hacerlos de mejor fortuna que a los mendigos, op. cit., p. 25-26. 
En poemas posteriores de esta breve sección inicial del libro, el yo adopta un tono marcadamente epistolar ${ }^{27}$ con el que Aconseja a su hermana que no se dé a la poesia y Habla con don Francisco de Quevedo en las sátiras a los cornudos ${ }^{28}$. La práctica de la escritura se erige, paulatinamente, en motivo de gran recurrencia, alcanzando incluso reflexiones de cierta profundidad: «si puede ser que de repente muera / aun antes de acabar este soneto ${ }^{29}$. Tal repliegue de escritura y vida, con la directa implicación de sujeto poético y sujeto histórico, conduce a incertidumbres que se generan en el propio proceso de escritura, como evidencia el soneto en que $A l$ ir a escribir, confiesa su desconfianza:

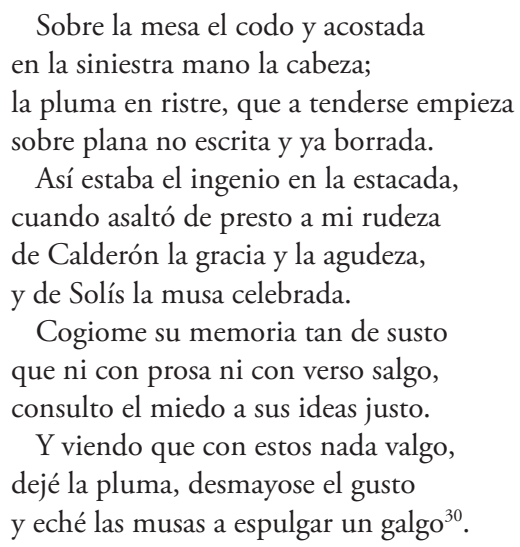

Los motivos de la desconfianza expuesta en el poema tienen que ver con la paradójica certeza de que existe una alternativa al esclerosado modelo de escritura que se basa en el vuelo del ingenio, el rapto poético y la inspiración. Frente a la abstracción inmaterial que sugiere la manera de componer convencional, el soneto torresiano presenta la imagen de un escritor que manufactura los poemas, alejando de sí a las musas y a los modelos de autoridad, abriendo de ese modo el camino hacia una nueva concepción del oficio, hacia un numen distinto. Se dibujan con nitidez, a partir de este soneto, los perfiles de uno de los ejes temáticos que vertebran los Entretenimientos: la escritura poética es un asunto relacionado con la técnica y, por tanto, se puede aprender, practicar y mejorar, hasta concretarse manualmente, tal y como se plasma en el soneto. Esta diferente concepción del escritor en el contexto social explica, por ejemplo, el gusto reiterativo por señalar paratextualmente a lo largo de la antología todos los poemas surgidos como poeta repentizador. Ello se debe a que la repentización es el ejemplo máximo de habilidad y técnica versificatoria, así como prueba irrefutable de oficio poético y, por ende, de distinción.

27. Para el sentido que va adoptando lo epistolar en la poesía bajobarroca vid. el trabajo de Pedro Ruiz Pérez, «La epístola poética en el bajo barroco: impreso y sociabilidad», en este mismo volumen.

28. Op. cit., p. 9 y $13-14$.

29. Op. cit., p. 10.

30. Op. cit., p. 11. 
La voz poética que reside en los textos del Entretenimiento reivindica la profesionalización letrada por muy diversos medios. Son muy ilustrativos al respecto los versos del poema Describe su vida en la Corte, en los que declara ufano: «debo a mis almanaques mi vestido / y me paga la musa mi techado» ${ }^{31}$. Siendo la escritura el medio de vida de Villarroel, y también su motivo de orgullo, no era extraño que se valiera de sus textos poéticos para defenderse de cualquier opinión o intrusión que pudiera considerar ofensiva, algo que se aprecia con claridad en el poema que dirige $A$ un letrado que escribió un papel contra la Astronomía ${ }^{32}$. Y ello a pesar de que él mismo utilizó los pronósticos y la astrología "con tan desmitificadora distancia, con tan burlesca ambigüedad, que cada uno de sus almanaques se convierte en una contrahechura humorística del género ${ }^{33}$. Pero una cosa era saberse manipulador exitoso de una tradición y otra muy distinta permitir que se pusiera en peligro su negocio.

Por ello arroja versos afilados contra las críticas a esta práctica que tantos beneficios le reportaba, afirmando que «miente quien dice que el astral oficio / es oficio de locos o indiscretos» ${ }^{34}$. En general, Torres Villarroel revistió a sus pronósticos con una pátina de cientifismo que compartieron muchos otros de sus escritos. La ciencia, que tanto interesó al Piscator, aparece en su obra desde una perspectiva plural: como forma de pensamiento sometida a la comprobación y alejada del dogmatismo escolástico, como instrumento de dignificación personal y como objeto susceptible de divulgación y venta ${ }^{35}$.

Podría extrañar, de acuerdo con la tradicional concepción de moralidad, la reiterativa presencia que en esta serie de sonetos morales tienen los temas de carácter económico, más propios, a priori, de librepensadores del norte de Europa que del castizo catolicismo peninsular. Pero ocurre que los tiempos estaban cambiando, y Villarroel con ellos, de modo que la moralidad que propugna el salmantino y justifica la agrupación de estos poemas funciona aquí como una norma de conducta relacionada con patrones de sociabilidad distintos, no apegados a la trascendencia religiosa de antańo, sino a las maneras de vida del aquí y del ahora. "Vale más de este siglo media hora / que dos mil del pasado y venidero» ${ }^{36}$, escribe Villarroel para refrendar el apego que tenía a su presente y a su circunstancia, con el desdén que ello implica hacia la nostalgia de épocas pretéritas que se apreciaban como mejores.

La circunstancia es, por tanto, motivo recurrente, referente reiterativo y basamento insustituible del poemario, pues sobre la referencia paratextual a la historicidad que determinó la escritura del poema adquieren sentido y orden las

31. Op. cit., p. 6.

32. Op. cit., p. 14.

33. Fernando Durán López, «A vueltas con la Vida de Torres Villarroel: ¿̨relato picaresco o autobiografía moderna», Edad de Oro, n 31, 2012, p. 155.

34. Op. cit., p. 21.

35. Sobre esto vid. Manuel María Pérez López, «Para una revisión de Torres Villarroel», en M. M. Pérez López y E. Martínez Mata, Revisión de Torres Villarroel, Salamanca, Universidad, 1998, p. 19.

36. Op. cit., p. 11-12. 
distintas composiciones en el libro. A modo de ejemplo, se puede mencionar el soneto compuesto Con ocasión de tener ya escrito el Piscator del año de 1726 y haber sacado el Hospital de Madrid un privilegio para que no se imprima, escribe a su Alteza el Señor Don Carlos para que permita que se imprima en su cuarto, donde tiene por diversión una imprenta ${ }^{37}$.

El encabezado conecta el poema con el problema concreto que afectaba al calendario de 1726, retenido a falta de aprobación. Villarroel, entonces, dirige un memorial al monarca del que no obtiene ninguna respuesta. Decidido a sacar adelante su proyecto se dirige en septiembre de ese año a El Escorial, donde estaba instalado el monarca. En octubre, con ocasión del cumpleaños de la reina Isabel de Farnesio, se organiza una celebración a la que asiste el Piscator. Allí coincide con el monarca y le propone que estampen el calendario en su habitación, aprovechando que disponía allí de una pequeña imprenta.

La variedad de esta sección de sonetos morales alcanza incluso a poemas escritos para otras obras y publicados en sus preliminares, como el soneto que dedica a las Morales y políticas reflexiones sobre la vida de Numa Pompilio (1728), de Fausto José Pereira ${ }^{38}$, o el que incluyó en los preliminares de las Glorias de España (1736) de Juan José de Salazar ${ }^{39}$, volumen paradigmático de la tendencia a conjugar historia y poesía, cada vez más en boga. Este último poema, dicho sea de paso, se cambió, bien por error o por actualización consciente, en su verso tercero, el cual fue impreso paratextualmente en 1736 como «en locución, noticia y argumento», en tanto que en el de dos años más tarde se remoza por «en locución, doctrina y argumento». La «noticia» conectaba con la inmediatez de la circunstancia del momento actual, pero acaso la «doctrina» cuadrase mejor que esta en una sección de sonetos morales. Sea como fuere, este soneto enlazaba cronológicamente con lo más próximo al itinerario vital del escritor en el momento de imprimir el poemario de 1738, actualizando sus entretenimientos ciudadanos previos (u ocios políticos) de 1726 .

A los primeros 59 sonetos de tono moral siguen otros 82 que se agrupan bajo el marbete de Sonetos amorosos ${ }^{40}$. Una sección denominada como tal y dirigida en su inicio a una dama poética de nombre Filis bien podría inducir a pensar en un seguimiento del modelo quevediano. Sin embargo, desde el comienzo se puede intuir una distancia con respecto a dicho patrón compositivo, por medio de la relativización, tan del gusto torresiano ${ }^{41}$, del motivo amoroso, ya que en los siguientes poemas de esta segunda sección las apelaciones a la dama se ensanchan con otras muchas referencias a mujeres distintas, lo que rompe con el axioma máximo de la lírica de inspiración petrarquista y platónica de la unicidad de la amada.

37. Op. cit., p. 26-27.

38. Op. cit., p. 28.

39. Op. cit., p. 31-32.

40. Op.cit., p. 32-73.

41. Pérez López señala que "en el plano literario" se vale Torres Villarroel de "variados recursos de relativización y ambigüedad, que expresan eficazmente una lúcida conciencia de la complejidad de la realidad y la dificultad de hallar la verdad», op. cit., p. 28. 
Con este procedimieto se deja al descubierto la convencionalidad de una retórica estandarizada, así como su honda tradición literaria, lo cual se hace patente desde el comienzo del itinerario de la lectura, ya que si en el tercer poema de la serie de sonetos amorosos Encarece a Filis sus afectos ${ }^{42}$, en el que le sigue Encarece a Filis sus afectos con imitación de el Camoes ${ }^{43}$. La ampliación del motivo a través de la referencia al poeta luso evidencia la actualización de la reescritura y la dimensión no vivencial del yo poemático, lo que se extiende al siguiente soneto, escrito por El pastor Fabio a su adorada Filis ${ }^{44}$, en el que el entorno bucólico habla muy a las claras de un contexto idealista que se aparta de la concreta circunstancia de la mayoría de sus composiciones. Este mismo procedimiento se utiliza en el resto de los poemas ubicados al comienzo de la serie de sonetos amorosos, en los que se alude a la hermosura del cuerpo de Filis, la perfección de su espíritu, su firmeza y constancia en el amor, su llanto, su enfermedad, sus ojos o su belleza ${ }^{45}$.

La necesidad retórica de un referente poético femenino al que poder dirigir composiciones se expone y justifica con claridad diáfana en el soneto $A$ Filis, encareciendo su adoración, cuyos versos evidencian, asimismo, la oposición entre el «ayer» y el «hoy», el «ellos» y el «nosotros», que Pérez Magallón establece como una dialéctica propia y definitoria del nuevo pensamiento que aflora con los novatores ${ }^{46}$. Conforme a esto, el pasado se encapsula en el primer cuarteto del poema: «Góngora, Lope y otros, que la idea / de las musas fingieron altamente, / por objeto del numen elocuente / tuvieron su deidad, su Dorotea». A todo ello se contrapone un presente o «nosotros» identificado formalmente por medio de la primera persona: «Yo, Filis, discretísima Medea, / hechizo universal de lo viviente, / en tu belleza tengo reverente / mi ejercicio, mi gloria y mi tarea».

Cabría preguntarse qué Góngora fue el que leyó Torres Villarroel, o de qué manera lo hizo, para insertar la poesía del autor de las Soledades en la línea de la lírica amorosa. Desde luego, no parece que aquí se apele a una cuestión estrictamente textual o temática, en cuyo caso habría que desterrar al cordobés de esta sección del volumen, o a lo menos del soneto. Probablemente, se trae a colación al racionero por ser parte indisoluble del binomio lírico aurisecular que completaba el Fénix; de modo que el par Góngora-Lope, representativo de ese «ellos» o canon áureo que se aspiraba a sobrepasar, se define como representativo de una poesía de "fingimiento elocuente», parafraseando los versos del poema,

42. Op. cit., p. 34 .

43. Op. cit., p. 34.

44. Op. cit., p. 34 .

45. Op. cit., p. 37-45.

46. Jesús Pérez Magallón, Construyendo la modernidad: la cultura española en el tiempo de los novatores (1675-1725), Madrid, CSIC, 2002. Para el caso concreto de Torres Villarroel Iris M. Zavala sitúa al autor en un contexto de "guerra de estrellas y cometas», esto es, tensiones provocadas por los enfrentamientos entre astrónomos y astrólogos, fe y razón, lo que interpreta como una expresión de la querelle entre Antiguos y Modernos («Literatura popular novadora: lucha y caída de los astros», en I. M. Zavala, Clandestinidad y libertinaje erudito en los albores del siglo XVIII, Barcelona, Ariel, 1978, p. 168-215). 
la cual conectaba al referente textual con una «idea» de trascendencia elevadora o «deidad».

Frente a esto, el yo del poema apela a un horizonte que nada tiene que ver con una amada entendida como deidad trascendente, ya que la etiqueta Filis no propicia otra cosa sino el «ejercicio», la "gloria» y la «tarea», como remata el segundo cuarteto; o de acuerdo con Autoridades: el «oficio, empleo, entretenimiento y ocupación», "lo que ennoblece, ilustra y engrandece», así como la "obra o trabajo». La arquitectura del soneto, por tanto, contrapone dos tradiciones poéticas mediante la oposición de un amor del allá y otro del acá, un amor que tiene que ver con lo inmaterial de la idea fingida o con lo tangible y mensurable del trabajo letrado. En definitiva, un amor del ayer y del ellos o del hoy y del nosotros; en suma, de la circunstancia presente que reclama una textualización distinta.

Esta oposición, que puede apreciarse con nitidez en el soneto referido, tiene su correlato macroestructural en la manera en que se articulan los poemas en la sección de los sonetos amorosos. Así pues, y del mismo modo que el soneto de Torres Villarroel sugiere un recorrido en orden cronológico desde el pasado hasta el presente, también el itinerario de la lectura que propicia la ordenación de las composiciones en esta segunda sección del libro induce a un comienzo en el ayer del tópico amoroso (aunque con los indicios de inflexión ya apuntados) que evoluciona en dirección hacia un presente que dota a los textos de una circunstancia nueva, más extratextual que intertextual.

Así pues, si la primera veintena de sonetos amorosos están dedicados en exclusividad a Filis, formalización prototípica de una retórica asentada en la ficción poética, tras su despedida («Adiós Filis, adiós, dueño adorado») se prosigue con una serie de composiciones que tratan los mismos asuntos de los poemas anteriores, aunque dirigidos ahora a mujeres diversas, algunas de ellas con nombre y apellidos. De ese modo, la afirmación del último de los sonetos A Filis, "aún más allá del fin he de adorarte», contrasta grandemente con el siguiente poema, en que Dice una dama la pureza de su adoración en términos llamativamente distintos a los que cabría esperar de la Filis quevediana:

\footnotetext{
Ídolo venerable, quien cumplido venera religioso $\mathrm{mi}$ respeto, oye mi puro amor en un soneto, con licencia de Dios y tu marido ${ }^{47}$.
}

Al no ser ya una prototípica Filis literaria del ayer, sino una textualización presente de cualquier circunstancia cotidiana del hoy, la participación necesaria de los órdenes divino y humano se convierte en premisa inexcusable para el cortejo o galanteo, práctica muy próxima al chichisveo que se había criticado en alguno de los sonetos anteriores. La contradicción o paradoja es algo consustancial a la escritura torresiana. Aquí, sin embargo, la dualidad de perspectivas es coherente con la separación temática entre los sonetos de

47. Op. cit., p. 45. 
moralidad y los de amor. Además, los versos citados prueban que la tematización amorosa de antańo, que requería del secreto clandestino, se había trasvasado definitivamente a la esfera de lo público compartido como un patrón de sociabilidad convencional y estandarizado ${ }^{48}$. Si pudiera quedar alguna duda sobre esta superación del paradigma quevediano, y todo lo que ello supone con respecto al abandono, al menos parcial, de los modelos auriseculares, se solventa con el poema que sigue a este en la serie de sonetos amorosos, titulado Mándale Filis hacer un soneto bueno al poeta:

No puede ser mandato, será enredo de tu chanza burlona y peregrina. ¿Piensas que puedo hacer, Filis divina, milagros como tú? Pues no, no puedo.

¿Yo buen soneto? Búscalo en Quevedo ${ }^{49}$.

El poema remite a Quevedo, pero sobre todo apela a la superación de un paradigma que buscaba en la indagación amorosa la sublimación del yo poético, de una individualidad en sentido genérico que no se concretaba, sin embargo, de un modo unívoco, desde el punto de vista material e histórico. Realzando la dimensión literaria y ficcional de estos poemas se rebajan los tópicos y se ponen a ras de suelo para acercarlos a la nueva función que cumple la poesía de anécdota o temática amorosa en el ámbito de relaciones de su época. La banalización del asunto despoja al discurso poético de la elevación y trascendencia de antaño, y justamente lo conecta, podría decirse que de manera empírica, con la realidad inmediata de sujetos históricos específicos, tales como Manuela de Guadalajara, María Antonia de Castro, Antonia Mejía, Francisca Vallejo o María Antonia de Chaves. La orientación hacia lo real histórico establece el marco de relaciones unívocas y específicas de quien escribe, de modo que los poemas no son la construcción textual de la individualidad, en la que otros lectores pudieran reconocerse, sino la construcción del personalismo de Torres Villarroel, quien se cuenta y muestra a sí mismo a través de sus textos.

$\mathrm{Si}$ al inicio de los sonetos amorosos se dirige un poema $A$ Filis dándole los buenos buenos días (p. 40), conforme avanza la serie aparecerá otro $A$ una dama, dándole los buenos días (p. 47). La continuación del motivo, modificado mediante la permutación de la destinataria, no supone seguimiento de lo planteado al comienzo, sino la constatación de que el prototipo de Filis, con todo lo que ello implica, se había actualizado de acuerdo con las nuevas prácticas de sociabilidad. En requerimiento de amores se destinan composiciones a Laura y Laurencia, respectivamente; en tanto que Clori y Lesbia aparecen en los versos con ocasión de enfermedades y convalecencias varias. Y ello no carece de importancia, pues supone, de un lado, la recreación de contextos muy próximos a lo consuetudinario, en una mezcla evidente de situaciones de sociabilidad

48. Sobre esto vid. Carmen Martín Gaite, Usos amorosos del dieciocho en España, Madrid, Siglo XXI, 1972.

49. Op. cit., p. 46. 
presentes con damas literarias de antaño; a lo que se suma el componente de exclusiva individuación unívoca que acarrea la enfermedad ${ }^{50}$.

Que los tiempos eran distintos a los de la centuria anterior y la poesía de amor muy otra se constata en buena parte de las piezas que conforman los sonetos amorosos. Entre otras razones porque los intereses económicos y el espíritu mercantil habían penetrado en el discurso del amor, entendido como reflejo de una nueva clase protoburguesa a la que Villarroel aspiraba a pertenecer. Es por eso que el requerimiento amoroso no servirá para el mejoramiento de un ente individual y conflictivo, sino para el perfeccionamiento del profesional de la escritura. Tal viraje se justifica en un soneto como aquel en el que se Pide a una dama su mano para decir la buena aventura ${ }^{51}$, poema en que la figura femenina sirve para que el autor certifique sus dotes como astrólogo. Y también de peticiones y agradecimientos trata el soneto que le sigue: Habiéndole pedido a una dama un traje que tenía de serrana para una pastora de un nacimiento, que hizo en su casa de doña Josefa de Torres, hermana del autor, le escribió a esta dama dándole cuenta de todo en este soneto:

Cesó de los ensayos lo violento, empezó con la fiesta la alegría, el acto sin desgracia proseguía, con que salió de madre el Nacimiento.

Don Juan hizo a Luzbel, con ardimiento; José, a San José; Frasca, a María; mi hermana, una pastora que vestía tu condición, tu traje y tu tormento.

Yo hice un pastor amante y no creído, quizá porque, con traje de serrana, lo falso le pegó y lo fementido.

Pues, ¿qué espero de ti, dulce tirana, cuando el contacto solo del vestido vuelve en desprecios el amor de hermana?

El poema debió dirigirse inicialmente a un entorno de lectores que conocían, necesariamente, los códigos y los juegos parateatrales del contexto restringido en que tuvo lugar el evento festivo. Al imprimirse y ubicarse en la dispositio de los sonetos amorosos, el epígrafe del poema recrea para el heterogéneo lector masivo un contexto de relaciones letradas en el que lo amoroso no es sino otra máscara intercambiable más del juego literario; pero se trata ya de un juego (o entretenimiento) no vinculado a la academia o a la corte, sino al salón dieciochesco.

La poesía como expresión de juegos dramáticos, o del teatro como juego y ocupación letrada, se hace más patente al final de esta sección de poemas, en donde dispone Villarroel una serie de textos apologéticos en defensa de un

50. Vid. Luis Fernández Cifuentes, «Enfermedad y autobiografía: sobre la "experiencia de la individualidad”", en M. M. Pérez López y E. Martínez Mata, op. cit., p. 155-171.

51. Op. cit., p. 56. 
grupo de actrices que eran de su predilección. En las casi veinte composiciones que cierran esta segunda sección de sonetos amorosos defiende Villarroel a las «farsantes» y ataca a aquellos que las critican, esgrimiendo como argumento irrefutable el éxito que tenían ante el público: «¿Cómo, siendo en el arte tan canijos, / de Antonia provocáis el sobrecejo, / cuando son sus aplausos tan prolijos ${ }^{\prime 2}$. El aserto supone un seguimiento actualizador de los postulados lopescos, escritor a quien Villarroel tiene muy presente; tanto que en estos poemas de encomio dramático se utiliza al Fénix como recurrente motivo de imprecación: "Válgame Apolo, ¿qué dijera Lope / al escuchar tan disonante tropa " $^{53} \mathrm{o}$ "Válgame Lope, ¡cuánto poetilla / cencerra! ¡Cuánto lírico muleto! / Tontos de afolio, que hacen un soneto / como habían de hacer una morcilla» ${ }^{54}$.

Las defensas que de las profesionales del espectáculo teatral hace Villarroel se pueden explicar por la proyección de sus propios intereses mercantiles en lo referente al negocio literario de masas, el cual conocía bien por el éxito de sus calendarios, tan del aplauso popular. Pero más difícil resulta justificar que estos 19 sonetos dirigidos a actrices, como explica el extensísimo epígrafe que les antecede ${ }^{55}$, y que ya habían sido estampados con anterioridad, se recopilen en un poemario de autor y se coloquen, justamente, al final de una sección de sonetos amorosos.

Cabe preguntarse qué podía haber de amor en estos poemas a cuatro cómicas. Se puede conjeturar que nada relacionado con el sentimiento de exclusividad que pudiera preludiar la Filis del principio, y mucho menos una moralidad elevadora, tratándose, como es el caso, de profesionales del teatro. Es difícil encajar estos poemas, como otros muchos de la serie, de acuerdo con una idea de cancionero amoroso o de poesía de amor si se asume que los versos de Villarroel son una extensión degradadora de los modelos auriseculares, pues se trata de algo claramente distinto.

El matemático salmantino había leído e incorporado a los autores de la tradición literaria previa en su discurso literario, lo que generalmente se interpreta, para el caso de su producción poética, como un seguimiento ramplón y empobrecedor de la tradición previa. Cabría considerar que también quienes elaboraron el Diccionario de Autoridades habían incluido a Quevedo o

52. Op. cit., p. 68.

53. Op. cit., p. 69.

54. Op. cit., p. 72.

55. Geriganzo con su Catalinón y Girapliega, a los poetas duros y cacochimicos, que tienen obstinado el vientre de el celebro. Es un salpicón contra los que son impotentes de meollo y eunucos de fantasía para producir la agudeza: salvajes tolerados que están metidos de mogollón en la tropa de los discretos y viviendo de gorra en el coro de los legitimos hijos de las musas. Zahiérense con este jeringatorio las coplas con que están cagando las resmas y llenando los papeles de gargajos de consonantes en ofensa de las cómicas, alabándolas en estilo bruto con décimas de coz y bocado. Celébranse en este papel las bellezas, chistes, habilidades y gracias de las cuatro que no se comprehendieron en el antecedente. Es, a saber, María Antonia de Castro, Antonia Mejía, Francisca Vallejo y la Chaves. Y se les amonesta a los poetas pellejos que dispongan el nalgatorio para otro jeringazo con que se les salpicará de apodos en pasando la Cuaresma, op. cit., p. 64. 
Góngora, y habían citado a Lope hasta la extenuación. Y sin embargo, no se puede sostener por ello que su labor suponga una copia degradada de Correas o Covarrubias. Antes bien, se entiende como un elemento de progreso y adecuación a los nuevos tiempos y a los nuevos intereses, desde una perspectiva más pragmática y acorde con las ideas de progreso y pensamiento científico provenientes de Europa (si es que España no era Europa).

Desde esta perspectiva, había amor, y mucho, en los sonetos dirigidos a las cómicas. Pero era este un amor por el éxito y el dinero que se conseguía a través del aplauso. La formalización de los poemas se basa, en muchos casos, en las imágenes heredades, pero el sentido es muy distinto del que tenían los textos poéticos en el siglo anterior, pues muy otras eran las complejidades de la sociedad en que vivía Villarroel.

La modernidad de Villarroel, indiscutida para sus acercamientos a géneros populares, a lo científico o a la prosa de ficción, no se debe a una ruptura absoluta con lo anterior en todos los órdenes, sino a su capacidad para asimilar y producir un discurso distinto a partir de los mimbres que le proporciona la tradición previa. Esa misma modernidad se hace extensible a su poesía, que no plantea una ruptura de índole formal, sino conceptual, con respecto a los modelos auriseculares. Ello explica, por ejemplo, que entre los poemas amorosos se incluyan una pieza escrita con ocasión de una toma de velo ${ }^{56} \mathrm{o}$ un poema elaborado desde el apartamiento del mundo:

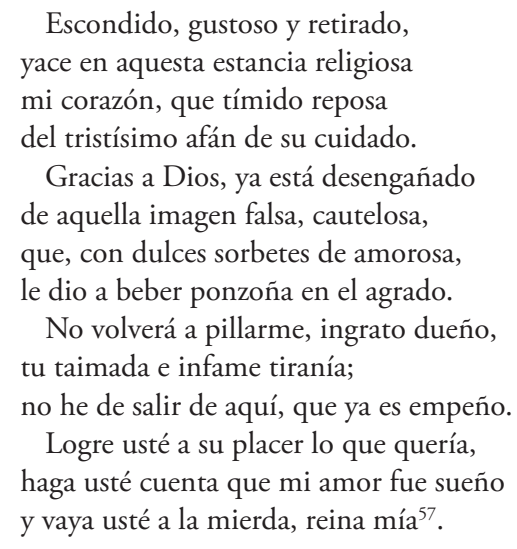

El final del soneto puede ser bien indicativo de la actitud de Villarroel con respecto a la tópica amorosa heredada del siglo anterior, que utiliza en la construcción formal y en lo referente al arsenal de imágenes y motivos, pero no en cuanto a la carga conceptual que todo ello acarreaba. Así, el sufrimiento estoico provocado por la imposibilidad de alcanzar lo que se anhela no parece

56. A una señora hermosa con extremo que iba a entrar en religión, op. cit., p. 62. Para este subgénero vid. Nieves Baranda, "Cantos al sacro epitalamio o sea pliegos poéticos para las tomas de velo. Deslindes preliminares", Bulletin Hispanique, n 113.1, 2011, p. 269-296.

57. Escribe enfadado a una dama desde un retiro religioso, op. cit., p. 60. 
una opción válida para explicar la complejidad del yo poemático bajobarroco, y mucho menos para dar testimonio de una realidad en la que el pensamiento científico comenzaba a relativizar la noción monolítica del modo de ser de las cosas y del sentido de la trascendencia seiscentista. El amor como obediencia debida era definitorio de un mundo y un sistema de pensamiento que se pretendía dejar atrás (o mandar muy lejos), como se comprueba en la evolución operada en los sonetos amorosos del Entretenimiento de Torres Villarroel.

La sección de sonetos amorosos se culmina con el titulado Dice a Filis lo imposible de copiar su hermosura ${ }^{58}$, poema que se coloca como cierre de la serie por un doble propósito de equilibrio editorial en el orden dispositivo del volumen: de un lado, para conferir unidad a toda la parte, que se había iniciado con los textos dirigidos a Filis; de otro, para conectar los sonetos con la serie de silvas posteriores, que se abre justamente con una Silva amorosa a Filis ${ }^{59}$.

Así pues, a las dos primeras partes de sonetos sigue un bloque más amplio conformado por composiciones extensas, el cual se inicia con varios poemas destinados a esta recurrente etiqueta femenina: tres silvas, además de una octava. Dichos textos dejan paso a romances escritos para ocasiones que se describen con precisión notarial (o matemática) en los epígrafes que los encabezan. Y ello es así desde la primera de estas piezas octosilábicas, el extenso Romance sayagués a la colocación de la catedral de Salamanca. Año de 1733. Pídese en estilo aldeano de los payos de tierra de Salamanca un romance haciendo relación de todas las fiestas, y escribió don Diego de Torres el siguiente ${ }^{60}$. El poema es una relación de fiestas que había sido ya encargada, escrita y difundida cinco años antes. Pero su ubicación en un poemario de autor y, sobre todo, la opción reiterada por marcar paratextualmente la ocasión que propició el texto aportan un nuevo sentido al poema, que en ningún momento se desgaja de la circunstancia que propició su escritura. Villarroel compuso inicialmente el romance para una academia («aquesto no importa nada, / ni es de la historia ni asunto / que la Academia me encarga ${ }^{61}$ ), adecuando su discurso a las prerrogativas impuestas en cuanto al uso del sayagués. Inserto como un personaje que observa las fiestas, va describiendo en este estilo rústico hasta lo más particularizado de las reacciones de los presentes, lo que supone dar cuenta incluso de los «los jijíes y ja jaas» ${ }^{62}$ de los asistentes.

El constante interés por presentar la circunstancia de la escritura y proyectar así en el libro la historia personal de quien escribe hace que Torres Villarroel aluda en el romance, igual que en algunos de sus sonetos, al destierro real que sufrió durante los años $1732-1734^{63}$ : «Y aquesto escribió, juntando / voces y noticias

58. Op. cit., p. 73.

59. Op. cit., p. 74-76.

60. Op. cit., p. 80-106.

61. Op. cit., p. 82.

62. Op. cit., p. 94.

63. El destierro de Villarroel se relata en el Cuarto trozo de su Vida. Vid. también Guy Mercadier, "El destierro de Diego de Torres Villarroel en Portugal: dos memoriales inéditos", en Actas del IV Congreso Internacional de Hispanistas, II, Salamanca, Universidad, 1982, p. 269-275. 
vagas / quien gemía en su destierro / mientras los demás se holgaban» ${ }^{64}$. Al no haber podido participar de las fiestas en primera persona, se valió de las noticias enviadas por sus amigos. La especificación de esta circunstancia redundaría en un indirecto enaltecimiento de la técnica versificatoria de Villarroel, que le permite crear una imagen real de lo no visto ni oído, sino como reelaboración poética de lo relatado por escrito.

El afán por hacer patente la escritura en el destierro reaparece de manera mucho menos tímida y solapada en el poema En día de cumpleaños de mi señora doña Joaquina Morales remitió desde Portugal este romance, cuyo primer verso especifica la fecha exacta en que tenía lugar la celebración: «el día nueve de mayo». En el romance, después de referirse al marido y los hijos de la celebrante, se extiende en referir las penurias que sufre en su obligado retiro portugés:

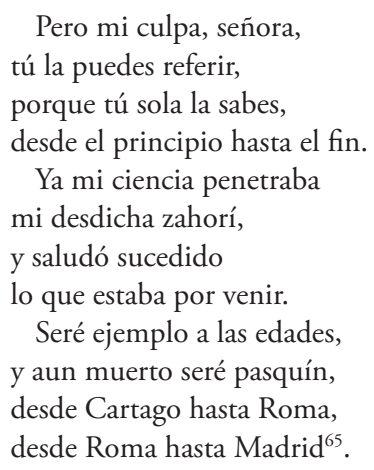

El poema sirve de exculpación justificativa de su condena, propiciada, según parece, por el éxito de la actividad profesional que más dinero y fama le reportó: los pronósticos. Con todo, se puede dudar de si realmente escribió este texto a dońa Joaquina; $y$, si en caso de hacerlo, lo mantuvo sin alteraciones para su publicación o si, por el contrario, lo actualizó a conveniencia. Sea como fuere, en el poemario aparece integrado como uno más de los eslabones que sirven para forjar la cadena de su vida como poeta profesional.

La presencia continua del exitoso escritor Villarroel en los textos dirigidos a mujeres de carne y hueso, muy distintas ya de las Filis ficcionales (o enmascaradas) de otras de sus composiciones, se prosigue con el romance que escribe a doña Ángela de Fuentes ${ }^{66}$ con ocasión de su cumpleaños. En el poema, la relación que se establece con la destinataria parece perseguir una cierta finalidad instrumental, pues tras el preceptivo elogio ("hoy es tu día y yo quiero / que mil de tus días veas ${ }^{67}$ ) se alude a asuntos que solo tangencialmente se pueden relacionar con lo que cabría esperar de una felicitación de cumpleaños: «En tu cielo he de estudiar / la Astrología moderna / y todos mis calendarios / 
he de hacer por tus kalendas" ${ }^{68}$. A partir de aquí, todo el poema se construye mediante la proyección del calendario que confeccionará para la dama. De este modo, el poema-calendario supone la proyección del propio Villarroel como profesional del negocio, que se encauza a través de la dedicataria de la composición.

En esta sección de poemas heterogéneos y extensos se incorporan, asimismo, varios romances presentados como cartas en verso. Alguna de estas composiciones probablemente fue compuesta para un contexto de academia, como la dirigida a Juan Calvo, músico de Medinaceli. Otras podrían haber sido misivas reales dirigidas desde la distancia, como la Carta escrita desde El Cubo de Don Sancho a don Baltasar de Herrera, beneficiado de dicho lugar, dándole aviso de las novedades de la aldea ${ }^{69}$, la que Escribe a su amigo don Juan de Salazar desde El Cubo, estando desterrado ${ }^{70}$ o la que Escribe desde Portugal a una señora cuyos titulos se expresan en el romance, refiriéndole algunos trabajos, y le suplica sus piedades ${ }^{71}$.

En la primera epístola aclara, desde el comienzo, los motivos de su escritura: «hoy, a falta de correo / te escribo por la estafeta»; y añade después que "de este modo mi destierro / paso hasta que el tiempo quieres ${ }^{72}$. La segunda de las epístolas conecta con el proyecto de construcción de una vida poética, al que nos hemos referido con anterioridad, como constata la imprecación que se dirige al destinatario del poema: «Leed o mandad leer / este romanzón insulto, / que es de mi vida un retrato / ni muy vivo, ni difunto ${ }^{73}$. El romance se construye como el testimonio de una conversión, no exenta de ironía ( «Ya no pienso en calendarios, / que solo escribo conjuros, / y para los camaristas / hago un tratado de pujos» ${ }^{74}$ ), con fecha y circunstancia exacta: $" A$ veinte del mes de mayo / esto escribe desde El Cubo / un desterrado que siempre / se firmará amigo suyo $»^{75}$. La tercera carta, mucho más extensa, se sustenta formalmente sobre la reiteración de la primera persona, que aparece como «yo»o «Torres» al principio de la mayoría de las estrofas que componen el poema.

Pero no se queda ahí Villarroel, pues la antología que construye se compone, como ya se indicó, de piezas muy heterogéneas que abarcan lo público, pero también lo privado que se hace público. Y justo en esta dirección apunta el romance $A$ la señora doña Teresa de Salazar y Morales, su abijada, explica el gusto que ha tenido en haberla logrado por su suerte y año en estas décimas y le envía un vestido ${ }^{76}$. El poema da cuenta de la relación presente del autor con la destinaria del poema y del vestido que este le envía como regalo, lo que origina la redacción de los versos. Pero el poema sirve, asimismo, para exponer la historia de esa relación desde sus orígenes: «Mi gloria, el primer pañal / yo te

68. Op. cit., p. 126.

69. Op. cit., p. 141-149.

70. Op. cit., p. 149-156.

71. Op. cit., p. 156-172.

72. Op. cit., p. 141 y 142.

73. Op. cit., p. 150.

74. Op. cit., p. 154.

75. Op. cit., p. 156.

76. Op. cit., p. 168-169. 
vestí y te limpié / de aquella roña con que / nos envía el natural» ${ }^{77}$. No todas las facetas que Villarroel publicita de su vida resultan tan ricas y prolijas en detalles prescindibles y generalmente obviados, como el cambio de pañales, cargados de «roña», que los unió para siempre.

Mucho menos humanas o privadas y más literarias o públicas resultan las casi treinta composiciones finales de la segunda parte de la antología poética, que remarcan el destacado papel de Torres Villarroel en academias, certámenes y celebraciones de variada índole. Se recopilan entonces 27 poemas que dan testimonio, por ejemplo, de su participación como presidente de una academia organizada en casa de los marqueses de Flores Dávila ${ }^{78}$, composición que se imprime acompañada de varias anotaciones a los márgenes. Tales indicaciones se utilizan para esclarecer algunas imágenes y alusiones de carácter culto, pero sobre todo para aclarar las referencias al marqués de Flores Dávila o a Zúñiga, general de la Armada, así como a otros integrantes del círculo académico del que Villarroel da cuenta en los versos, pues de no existir dichas notas sería imposible de identificar para un lector ajeno al entorno de sociabilidad en que se compuso el texto.

La variedad y mixtura que caracterizan a esta parte del libro de poemas se comprueba con las sucesivas composiciones, entre las que se pueden destacar el vejamen que escribió en el certamen organizado con motivo de la traslación de los restos de san Juan de Mata, culminado con una llamativa imprecación: «mandad, por Dios, que se imprima / pues bien sabéis que es lastima / que se pierda este papel ${ }^{79}$; o el poema dirigido Al marqués de Almarza, mandándole pedir un cerdo para su padre, en cuyos versos ruega discreción para que su progenitor no se entere del negocio, pues en ese caso, y aun siendo pobre, rechazaría el cochino. Este poema se complementa con las quintillas Habiendo correspondido dicho Señor a esta súplica, escribió el autor a su padre estas, en donde ofrece Torres Villarroel una distinta versión de lo ocurrido, para adaptar los hechos a un receptor diferente. Los versos revelan entonces la capacidad de la poesía para maquillar la realidad y clarifican el sentido que desde esta perspectiva adopta Talía, musa benefactora de un poeta de tal numen, capaz de obtener réditos por la excelencia de sus versos:

\footnotetext{
Yo, padre, aunque ya sabía sus espíritus gallardos, a pedir no me atrevía; mas valime de Talía, que es musa de los petardos [...]

$\mathrm{Ni}$ al vecino ni al padrino deis morcilla ni asadura; vaya y hágase el vecino otro hijo que a copla pura sepa ganar un cochino ${ }^{80}$.
}

77. Op. cit., p. 168.

78. Op. cit., p. 204-210.

79. Op. cit., p. 225.

80. Op. cit., p. 228. 
Más allá de la nueva reafirmación autorial, sustentada sobre algo tan material y mundano como el trueque de un cerdo por un poema, el texto aclara que la predilección por Talía obedece a los vínculos de esta musa con la «poesía petarda» (de estafa o engaño ${ }^{81}$ ) que representa el propio Villarroel y, por extensión, sus juguetes o entretenimientos impresos. Esta musa es, en suma, la encarnación de un numen que por la vía del entretenimiento y el engaño (o la ficción) permite obtener cochinos u otros beneficios de variada índole a quien esgrime los versos con la debida pericia.

Siguen a este otros varios poemas escritos para describir las fiestas madrileñas de san Isidro del año 1735; textos a la astrología; varias composiciones sobre pronósticos del ańo 1725, en un certamen organizado por la Universidad de Zaragoza para festejar a la Virgen del Pilar; un poema por la muerte del monarca Luis I y otro a su sepulcro; quintillas para describir una tertulia de amigos; repentizaciones dirigidas a la Virgen María o a dońa Joaquina, dependiendo de la situación; un poema Remitiendo a un amigo unos garbanzos y orzuelos de Salamanca; así como otras quintillas y glosas elaboradas con motivo de academias, certámenes y ocasiones varias.

El libro se cierra con el extenso poema épico de la Conquista del reino de Nápoles por su rey don Carlos de Borbón ${ }^{82}$, compuesto en octavas y dedicado a la reina Isabel de Farnesio. Se dispone en el volumen acompañado de la dedicatoria en prosa y del prólogo al lector, tal y como había aparecido en la edición madrileña de 1735 . Se suele considerar que este poema épico está en la estela de Góngora, interpretación que puede matizarse en algunos aspectos, pues aunque es verdad que formalmente contiene cultismos que pudieran asimilarse al cordobés (pero también a otros muchos autores de la época), lo cierto es que la intención de describir un hecho de la realidad concreta de manera pormenorizada, hasta el punto de anotar en los márgenes precisiones de carácter léxico, histórico o incluso geográfico, no casa demasiado bien con la idea de ruptura gongorina. En todo caso, el modelo o fuente del poema no es algo en lo que merezca la pena ocuparse demasiado, pues el propio Torres Villarroel confiesa en su Prólogo al lector que toma como referencia la Nápoles recuperada (1651) de Esquilache. Además de para esto, Villarroel utiliza el paratexto para afirmar su voluntad de transgredir ciertas normas del género $y$, sobre todo, señalar que a pesar de la forma versificada, su texto es historia y no poema:

La observancia de las rigurosas leyes, tanto esenciales como accidentales del poema, es la que siempre me quitó la pluma de la mano y la osadía de la imaginación para desear tal obra. El Tasso, Castelvetro y otros muchos, explicando la Poética de Aristóteles, dan los cánones fieles para la expresión de los poemas; y ellos mismos los quebrantaron muchas veces en los suyos, siendo los varones más membrudos y sabios en esta casta de argumentos. Yo he contentado al ansia de escribir las glorias de nuestros españoles

81. De acuerdo con Autoridades (1737) "petardo» tiene la acepción de «estafa u engaño que se hace pidiendo prestado y no volviéndolo».

82. Op. cit., p. 249-301. 
dictando en octavas solas esta conquista, por eso no pongo cantos y voy sucesivo con la narración de la historia, huyendo de todo lo que pueda parecer Poema ${ }^{83}$.

Aprovecha para dejar constancia de las circunstancias extraliterarias que determinan la composición del texto, como había hecho a lo largo de todo el volumen, y precisa que se aprestó a escribir esta obra finalizado su destierro:

Los primeros y principales pasos de esta inimitable acción sucedieron cuando yo estaba en donde no oí el comercio de las criaturas ni la voz de una gaceta; después de que, por la piedad del rey, mi señor, estuve entre mis amigos, junté sus voces y tal cual relación de esta Conquista y de estos son todos los materiales con que se ha levantado este pobre y breve edificio ${ }^{84}$.

Refiere después que no ha tardado demasiado en componer su texto y termina apelando a la originalidad de su obra y a su carácter como pionero en el terreno de la historia:

Por todas estas razones merece algún disimulo lo reducido y mal limado de la obra. Si me lo quieres conceder, te estimaré la piedad, y si no, me consolaré con la fortuna de haber sido el primero que ha trabajado algo en poner en público una acción que servirá eternamente de honra y gloria para nuestra España. Vale ${ }^{85}$.

La escritura de este poema es muestra, sobre todo, del agradecimiento de Villarroel por la merced concedida para regresar de Portugal. La impresión al final de su poemario supone el eslabón último de la cadena de su itinerario como escritor hasta el momento más cercano al presente, desde el que organiza su obra/vida poética.

\section{LA VIDA POÉTICA DE TORRES VILlarRoel: SOCIABILIDAD LITERARIA Y PROMOCIÓN AUTORIAL}

Las visiones que del entretenimiento ofrecen en sus poemarios respectivos Torre y Sevil, a mediados del XVII, y Torres Villarroel, pasado el primer tercio de la centuria siguiente, son representativas de la diferente valoración que la poesía había ido adoptando en las prácticas de sociabilidad del Bajo Barroco. Frente al entretenimiento académico de Torre y Sevil, ideado como un juego ingenioso por quien vive de menesteres distintos a los de la literatura y persigue una notoriedad fundamentalmente entre los pares, el entretenimiento de Torres Villarroel se vincula con algo mucho más profesional y personalista. Esta característica distintiva se concreta materialmente en la insistencia por recuperar a lo largo del volumen impreso hasta el último detalle de la circunstancia que propició la escritura de los poemas, actualizándolos así en la inmediatez del hoy y creando un itinerario poético que coincide grandemente con la trayectoria profesional de quien firma el libro.

83. Op. cit., p. 251.

84. Op. cit., p. 251-252.

85. Op. cit., p. 252. 
Gracias a esto, el poemario de Torres Villarroel se convierte en un completo muestrario de las diferentes modalidades en las que poesía y sociedad interactuaban en el Bajo Barroco, tanto en las esferas de lo privado como en las de lo público. Pero también evidencia el modo en que lo privado se hace público y se publicita a través del libro impreso. Además, las referencias a los vínculos del autor con representantes concretos de lo privado establecen un marco de relaciones dentro del cual los textos no dan cuenta de una individualidad en sentido genérico, sino de un yo asimilable, de modo personalista y exclusivo, al escritor Torres Villarroel.

En la fijación impresa de todas estas cuestiones cobra una importancia de primer orden la rotulación paratextual de los poemas, que sirve para restituir la historicidad originaria en la que se gesta el poema, a la par que permite establecer ciertas relaciones de coherencia discursiva con respecto al macrotexto que conforma el poemario. Por otro lado, la recreación de la circunstancia histórica acerca la poesía cada vez más a la realidad extratextual, hasta el punto de convertir a lo cotidiano en referente y objeto de la textualización. Siendo esto así, el recorrido por el libro va forjando el itinerario del poeta a través de sus textos, unos poemas que en casi ningún caso están despojados de la circunstancia empírica en que se escribieron. Y será entonces la circunstancia, fundamentalmente, la que justifique la redacción de los versos, pues son los epígrafes de las composiciones los que permiten explicar la capacidad versificatoria de quien escribe de un modo tan variado y versátil: ya sea a Filis en su escritorio o al amor de repente; a la muerte de un rey en unas fiestas o a la de un caballo en una academia; para saludar los buenos días, tanto a una mujer tópica como a una dama con nombre y apellidos; para ensalzar una toma de velo o la colocación de una iglesia en estilo sayagués.

El poemario es así la construcción material de una vida, no en prosa de ficción, sino en verso de circunstancia objetivable y varia. El recorrido por el libro, entonces, permite la reconstrucción del itinerario profesional del autor Torres Villarroel, quien se muestra como orgulloso productor de poemas al servicio de cualquier necesidad o circunstancia; y todo ello sin menoscabo del acontecer específico del autor histórico.

Estos vínculos entre su Vida literaria, en prosa, y la vida que construye en su poemario quedan claramente reflejados en el rótulo que encabeza la sección de las coplas compuestas de repente (p. 244-248): Para que se conozca lo copioso $y$ abundante de la vena poética de don Diego de Torres Villarroel pondré aqui algunas coplas que hizo de repente, en algunas casas de Madrid, que las escribieron por curiosidad. Y fue tan excelente en el arte de versificar de repente que hablaba con más facilidad y prontitud en verso que en prosa, como se dice más largamente en su Vida ${ }^{86}$.

La Vida aludida desde el paratexto de 1738 es la famosa obra en prosa que tantos quebraderos (críticos) de cabeza ha ocasionado ${ }^{87}$, y en cuyas páginas

87. Para un balance crítico y estado de la cuestión sobre las interpretaciones de la Vida, así 
alude el autor, efectivamente, a su poesía impresa. Así, por ejemplo, cuando en el Cuarto trozo describe ciertos entretenimientos con los que se distraía durante su estancia en casa de Juan de Salazar y su esposa Joaquina de Morales:

Representábanse entre nosotros, los familiares y vecinos, diferentes comedias y piezas cómicas (que algunas están en mi segundo tomo de poesías) en los días señalados por alguna celebridad eclesiástica, política o de nuestra elección ${ }^{88}$.

O también cuando el protagonista se refiere a su Peregrinación al Glorioso Apóstol Santiago de Galicia, señalando que «este viaje le tengo escrito en un romance que se hallará en el segundo tomo de mis poesías y en el Extracto de pronósticos, en el del año $1738 »^{89}$.

Lo más interesante del paratexto de sus Entretenimientos es que anticipa, desde su vida poética impresa de 1738, aspectos de la Vida en prosa que no daría a la estampa hasta cinco ańos más tarde, conectando de este modo ambas propuestas.

Si en su vida en prosa espiga Torres Villarroel anécdotas de su acontecer histórico y las reduce a literatura, en su vida en verso opera de una manera similar, pero mediante la selección y la disposición de lo ya escrito. Revisa entonces los poemas que había compuesto para acontecimientos concretos y personas particulares, y también una parte de los redactados como ejercicio de reescritura, caso de los dirigidos a Filis. Una vez escogidos los poemas representativos de su vida poética, los acompaña de paratextos que permitan entender tanto los vínculos con la realidad extratextual que condicionaron su escritura como también con la posición que ocupa cada texto en el conjunto del poemario. Y después de seleccionadas y presentadas las piezas procede a disponerlas como una cadena de textos que permiten conocer la realidad del sujeto histórico Torres Villarroel en su itinerario como escritor de poemas; lo que se pretende proyectar como el ascenso de un yo que, pese a ciertas similitudes formales, no puede identificarse ni con el ascensus del alma petrarquista ni con la problemática individualidad quevediana. Antes bien responde a un nuevo sujeto que vive en un mundo distinto y, por tanto, todo el libro está al servicio de la construcción de un relato y un retrato. El relato es el de las peripecias de un protoburgués manufacturador de versos en todo tipo de circunstancias, coincidentes con las situaciones que en la sociedad de inicios del XVIII requerían de poesía. El retrato es el del Villarroel que estaba novelando su Vida en prosa y que, recopilando y disponiendo en el espacio del libro los poemas escritos en las situaciones más dispares, construye el cancionero idóneo para el contexto del XVIII, esto es: el poemario en proceso de las experiencias del poeta en la sociedad de su tiempo.

como sus posibles modelos literarios, vid. el reciente trabajo de Durán López, op. cit.

88. Diego de Torres Villarroel, Vida, ed. Manuel María Pérez López, Salamanca, Edifsa, 2005, p. 156.

89. Op. cit., p. 180. 